\title{
Characterization and Regulation of p-Aminobenzoic Acid Synthase from Streptomyces griseus
}

\author{
By JOSÉ A. GIL, ${ }^{1}$ GERMÁN NAHARRO, ${ }^{1}$ JULIO R. VILLANUEVA ${ }^{2}$ AND \\ JUAN F. MARTÍN ${ }^{1 *}$ \\ ${ }^{1}$ Departamento de Microbiología, Facultad de Biología, Universidad de León, Spain \\ ${ }^{2}$ Departamento Microbiologí, Facultad de Biologia, Universidad de Salamanca, Spain
}

(Received 2 January 1985)

\begin{abstract}
p-Aminobenzoic acid synthase (PABA synthase) of Streptomyces griseus catalyses the conversion of chorismic acid to $p$-aminobenzoic acid (PABA), a precursor of the aromatic $p$ aminoacetophenone moiety of candicidin, a polyene macrolide antibiotic. This enzyme uses glutamine or ammonia as amino donors for PABA formation. Enzyme extracts converted $\left[{ }^{14} \mathrm{C}\right]$ chorismic acid to labelled PABA. PABA synthase was present in S. griseus IMRU 3570 only during the antibiotic producing phase. No detectable levels of the enzyme were found in cell-free extracts of nonproducing mutants of $S$. griseus obtained after UV mutagenesis. PABA synthase activity was found also in Streptomyces coelicolor var. aminophilus, producer of the polyene macrolide antibiotic fungimycin, but it was not present in extracts of several other streptomycetes that do not produce aromatic polyene macrolide antibiotics. PABA synthase (amidotransferase) activity was partially purified by DEAE-Bio-gel and Sephacryl S-200 filtrations. The estimated molecular weight was 50000. PABA synthase was repressed by aromatic amino acids and PABA but not by anthranilic acid. Inorganic phosphate strongly repressed but did not inhibit PABA synthase activity.
\end{abstract}

\section{INTRODUCTION}

Candicidin is an aromatic polyene antifungal antibiotic produced by Streptomyces griseus IMRU 3570. It contains the amino sugar mycosamine (3-amino-3,6-dideoxy-D-mannopyranose) attached glycosidically, and a $p$-aminoacetophenone moiety that forms part of the same carbon skeleton as the macrolide ring (Zielinski et al., 1979).

The $p$-aminoacetophenone aromatic moiety appears to serve as starter for the head-to-tail condensation of malonyl-CoA and methylmalonyl-CoA in the biosynthesis of the macrolide ring of candicidin (Martín \& McDaniel, 1975b; Martín, 1977). This aromatic moiety is formed from chorismic acid via $p$-aminobenzoic acid (PABA). PABA is a precursor for the biosynthesis of candicidin as can be concluded from the following evidence: $(a)$ the intact ring and the carboxyl group of PABA are incorporated into candicidin with a high efficiency (Liu et al., 1972; Martín \& Liras, 1976); (b) the inhibitory effect of tryptophan on candicidin biosynthesis is partially reversed by PABA, suggesting that the effect of tryptophan is due to starvation of the cell for PABA, thus preventing candicidin biosynthesis (Gil et al., 1980).

A large amount of PABA (up to $430 \mu \mathrm{g} \mathrm{ml}^{-1}$ ) must be synthesized in cultures of $S$. griseus which are able to produce up to $4000 \mu \mathrm{g}$ candicidin $\mathrm{ml}^{-1}$. The branch-point intermediate of the aromatic pathway giving rise to PABA in bacteria is chorismic acid. In Escherichia coli, Enterobacter aerogenes and Bacillus subtilis, and in the fungus Neurospora crassa, chorismic acid

Abbreviations: DMG buffer, dithiothreitol/magnesium chloride/glutamine/glycerol buffer; PLD medium, phosphate-limited defined medium; SPG medium, soya peptone/glucose medium; YED medium, yeast extract/glucose medium; PABA, $p$-aminobenzoic acid. 
is converted to PABA, in the presence of L-glutamine as amino donor, by PABA synthase (Gibson et al., 1964; Altendorf et al., 1971; Kane \& O'Brien, 1975). The relationship of PABA synthase to anthranilate synthase in $S$. griseus is intriguing. The pabA gene (PABA synthase) of $E$. coli has been sequenced and shown to be related to the $\operatorname{trp}(G) D$ gene of $E$. coli (Kaplan \& Nichols, 1983). The pab gene of $S$. griseus has been cloned (Gil \& Hopwood, 1983) and its expression is being studied in our laboratory.

It is therefore of interest to purify this enzyme and to study its regulatory pattern in $S$. griseus. The results reported here indicate that PABA synthase behaves as a typical enzyme of secondary metabolism and was detected only in strains producing aromatic polyene macrolides containing a $p$-aminoacetophenone moiety.

\section{METHODS}

Micro-organisms and growth conditions. The strains used in these studies were Streptomyces griseus IMRU 3570 and mutants derived from it. Non-producer mutants were obtained by UV light $(260 \mathrm{~nm})$ irradiation using a Desaga UV lamp located at a distance of $10 \mathrm{~cm}$ above the spore suspension. Under these conditions $0 \cdot 1 \%$ of spores survived after $3 \mathrm{~min}$ of UV treatment. Non-producing mutants were selected among the surviving $0 \cdot 1 \% . S$. coelicolor M145, S. coelicolor 2280 ( $\mathrm{pab}^{-}$) and S. lividans 66 were kindly provided by D. A. Hopwood, John Innes Institute, Norwich, UK. S. griseus NRRL 3851, a cephamycin-producing strain, was obtained from NRRL. $S$. coelicolor var. aminophilus IMRU 3865, the fungimycin producer, was supplied by L. E. McDaniel, Rutgers University, New Brunswick, NJ, USA. S. lividans JG10, a PABA auxotroph, was obtained from S. lividans TK 24 by NTG mutation (Gil \& Hopwood, 1983).

Cultures were grown aerobically in a medium supporting high antibiotic production which contained soya peptone $\left(25 \mathrm{~g}^{-1}\right)$, glucose $\left(65 \mathrm{~g}^{-1}\right)$ and zinc sulphate (0.5 mM) (SPG medium; Martin \& McDaniel, 1975a). The cultures were incubated at $32^{\circ} \mathrm{C}$ in $250 \mathrm{ml}$ triple-baffled flasks, containing $50 \mathrm{ml} \mathrm{SPG}$ medium, in a Gallenkamp orbital shaking incubator at $225 \mathrm{r}$.p.m. The production flasks were inoculated with $5 \mathrm{ml}$ of a $24 \mathrm{~h}$ inoculum grown in YED medium containing yeast extract and glucose (both $10 \mathrm{~g}^{-1}$ ). Candicidin production was determined spectrophotometrically at $380 \mathrm{~nm}$ after extraction with butanol (Gil et al., 1980).

Preparation of phosphate-limited resting cells. Candicidin-producing cells grown in SPG medium for $24 \mathrm{~h}$ were collected, washed twice with sterile saline $(0.8 \% \mathrm{NaCl})$ and resuspended at $5 \mathrm{mg}$ dry cell weight $\mathrm{ml}^{-1}$ in a phosphate-limited defined (PLD) medium containing $\left(\mathrm{mg} \mathrm{ml}^{-1}\right)$ : glucose, 50; L-asparagine, $10 ; \mathrm{ZnSO}_{4} .7 \mathrm{H}_{2} \mathrm{O}$, $0.02 ; \mathrm{MgSO}_{4} .7 \mathrm{H}_{2} \mathrm{O}, 0 \cdot 2 ; \mathrm{FeSO}_{4} .7 \mathrm{H}_{2} \mathrm{O}, 0.02 ;$ and $\mathrm{CuSO}_{4} .5 \mathrm{H}_{2} \mathrm{O}, 0 \cdot 02$. Unless otherwise indicated, no phosphate was added to the medium. In phosphate-supplemented media, $5 \mathrm{mM}-\mathrm{K}_{2} \mathrm{HPO}_{4}$ was used.

A $5 \mathrm{ml}$ sample of the cell suspension was incubated in $50 \mathrm{ml}$ triple deep-baffled flasks (Bellco Glass Inc., Vineland, NJ, USA) at 250 r.p.m. on an orbital shaking incubator (Gallenkamp).

Preparation of cell-free extracts. Cells grown in YED and SPG media, and incubated in the PLD medium or in minimal medium (MM; Hopwood, 1969) were harvested at different times of incubation (indicated in the text), washed with saline solution at $4{ }^{\circ} \mathrm{C}$ and stored as cell paste over liquid nitrogen. The frozen cells were resuspended in $10 \mathrm{~mm}$-potassium phosphate buffer, $\mathrm{pH} \mathrm{6.8,} \mathrm{containing} 1 \mathrm{~mm}$-dithiothreitol, $10 \mathrm{~mm}-\mathrm{MgCl}_{2}, 20 \mathrm{mM}-\mathrm{L}$ glutamine and $30 \%(\mathrm{v} / \mathrm{v})$ glycerol (DMG buffer) at $20^{\circ} \mathrm{C}$. In some experiments glutamine was not added to the buffer (see text). The cells were washed twice with cold $\left(4{ }^{\circ} \mathrm{C}\right) \mathrm{DMG}$ buffer and disrupted by treatment with glass beads for $2 \mathrm{~min}$ in a $\mathrm{CO}_{2}$-refrigerated MSK homogenizer (Braun, Melsungen, FRG). Cell debris was removed by centrifugation at $30000 \mathrm{~g}$ for $30 \mathrm{~min}$ at $4{ }^{\circ} \mathrm{C}$. The clear supernatants were dialysed overnight at $4{ }^{\circ} \mathrm{C}$ against DMG buffer or filtered through Sephadex G-25 previously equilibrated with cold DMG buffer. Protein was measured by the Lowry method with bovine serum albumin as standard and appropriate blanks to correct the interference of glycerol (Zishka \& Nishimura, 1970).

PABA synthase assay. The reaction mixture for PABA synthase (amidotransferase) activity contained $50 \mu \mathrm{mol}$

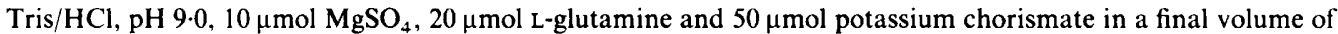
$1 \mathrm{ml}$. Concentrations of protein (enzyme) varied between 1.0 and $5.0 \mathrm{mg} \mathrm{ml}^{-1}$. Aminase activity was measured using $100 \mu \mathrm{mol} \mathrm{NH}_{4} \mathrm{Cl}$ as amino donor instead of L-glutamine, in a buffer without glutamine. Reaction mixtures were incubated at $37^{\circ} \mathrm{C}$ for $30 \mathrm{~min}$ and the PABA formed was measured by diazotization using a modification of the Bratton-Marshall technique (Jones \& Westlake, 1974), or spectrophotofluorimetrically (Kane \& O'Brien, 1975). Standard curves were prepared with pure PABA (Sigma). One unit of PABA synthase is defined as the amount of enzyme that produced $1 \mathrm{nmol}$ PABA per $30 \mathrm{~min}$. Specific activity is expressed as units per mg protein.

In experiments using ${ }^{14} \mathrm{C}$-labelled chorismic acid, the product of the reaction $\left(\left[{ }^{14} \mathrm{C}\right] \mathrm{PABA}\right)$ was separated from anthranilic acid by TLC on silica gel $G$ using benzene/ethanol $(80: 20, v / v)$ as solvent. PABA and anthranilic acid were detected with ninhydrin $(0 \cdot 1 \%, \mathrm{w} / \mathrm{v})$ in acetone. In this system, PABA and anthranilic acid moved with $R_{F}$ values of 0.43 and 0.54 , respectively. 
Preparation of partially purified PABA synthase. PABA synthase activity was partially purified by two sequential fractionation treatments. All the manipulations were carried out at $4^{\circ} \mathrm{C}$. The dialysed cell extract was chromatographed on a DEAE-Bio-gel (Bio-Rad) column $(30 \times 2.5 \mathrm{~cm})$. The column was washed with $500 \mathrm{ml}$ DMG buffer followed by $400 \mathrm{ml}$ of a linear gradient of $\mathrm{NaCl}(0$ to $1 \mathrm{M})$ in DMG buffer. The fractions of highest activity were pooled, dialysed, placed on a Sephacryl S-200 (Pharmacia) column $(43 \times 3.5 \mathrm{~cm})$ and eluted with DMG buffer. The active fractions were used as partially purified enzyme. The molecular weight of PABA synthase (amidotransferase activity) was estimated by gel filtration on Sephacryl S-200. The enzyme was stable when intact cells were stored over liquid nitrogen, but it lost $50 \%$ of its activity in one day when purified preparations were kept at $4{ }^{\circ} \mathrm{C}$. The stability of the enzyme was increased by glycerol addition (see Results).

Chemicals. Chorismic acid was prepared as the ammonium salt from the culture supernatant of Enterobacter aerogenes 62-1 as described by Gibson (1970). Ammonium chorismate was converted into the potassium salt before use. $\left[{ }^{14} \mathrm{C}\right] \mathrm{Chorismic}$ acid $\left[4.5 \mu \mathrm{Ci}(166.5 \mathrm{kBq}) \mathrm{nmol}^{-1}\right]$ was prepared by the same method using [U$\left.{ }^{14} \mathrm{C}\right] \mathrm{glucose}\left[230 \mathrm{mCi}(8.5 \mathrm{GBq}) \mathrm{mmol}^{-1}\right]$ as substrate. All other chemicals were obtained from commercial sources and were of the highest purity available.

\section{RESULTS}

\section{Properties of PABA synthase in cell-free extracts}

Properties of PABA synthase were examined initially using a dialysed cell-free extract prepared from $S$. griseus IMRU 3570 grown for $20 \mathrm{~h}$ in SPG medium. Under these conditions the enzyme had an absolute requirement for chorismic acid and either glutamine (amidotransferase activity) or ammonia (aminase activity). The amidotransferase was greater than the aminase activity by a factor of about five (an average of eight different experiments) and the optimum $\mathrm{pH}$ for both activities in vitro was $9 \cdot 0$ (Fig. 1). The product of the reactions was identified as PABA by TLC.

The amidotransferase activity of PABA synthase depended on the concentration of $\mathbf{M g}^{2+}$ in the reaction mixture. An increase in enzyme activity was observed up to $3 \mathrm{~mm}-\mathrm{MgSO}_{4} . \mathrm{PABA}$ synthase activity was partially inhibited by $\mathrm{Na}^{+}, \mathrm{K}^{+}, \mathrm{Ca}^{2+}$ and $\mathrm{Fe}^{2+}$ at $5 \mathrm{mM}$ and completely inhibited by the same concentration of $\mathrm{Mn}^{2+}, \mathrm{Ba}^{2+}, \mathrm{Zn}^{2+}, \mathrm{Hg}^{2+}, \mathrm{Cu}^{2+}$ and $\mathrm{Fe}^{3+}$. The inhibitory effect exerted by these ions was totally (e.g. $\mathrm{Na}^{+}, \mathrm{K}^{+}, \mathrm{Ca}^{2+}, \mathrm{Ba}^{2+}, \mathrm{Fe}^{3+}$ ) or partially reverted (e.g. $\mathrm{Mn}^{2+}, \mathrm{Fe}^{2+}$ ) by $5 \mathrm{~mm}-\mathrm{Mg}^{2+}$. Addition of EDTA at concentrations above $2 \mathrm{mM}$ completely inhibited the enzyme activity.

In crude cell-free extracts prepared in buffer without glutamine, glycerol or $\mathrm{Mg}^{2+}, \mathrm{PABA}$ synthase activity was stable for several weeks when stored at $-20^{\circ} \mathrm{C}$ or on liquid nitrogen. However, it lost its activity within $24 \mathrm{~h}$ when stored at $4{ }^{\circ} \mathrm{C}$. The addition of glycerol (up to $30 \%$ ) to the cell-disruption buffer greatly enhanced the stability of the enzyme in vitro. Addition of glycerol directly to the PABA synthase reaction did not stimulate enzyme activity. Glutamine and $\mathrm{Mg}^{2+}$ also enhanced the stability of the enzyme.

\section{In vitro conversion of $\left[{ }^{14} \mathrm{C}\right]$,chorismic acid to $P A B A$}

To prove that PABA synthase and not anthranilate synthase was being measured, experiments were done with $\left[{ }^{14} \mathrm{C}\right]$ chorismic acid $(1000$ c.p.m. in $100 \mathrm{nmol})$ as substrate, prepared as indicated in Methods. Reaction products were extracted with ethyl acetate ( $\mathrm{pH} \mathrm{4.7)}$ and separated by TLC (see Methods). Formation of $\left[{ }^{14} \mathrm{C}\right] \mathrm{PABA}$ occurred, but no radioactive anthranilic acid was found under the conditions used.

\section{Time-course of enzyme activity during batch cultures}

PABA synthase activity was induced when $S$. griseus was grown on SPG, a medium that supported good candicidin production. The amidotransferase activity increased rapidly, reaching a maximum at 18 to $20 \mathrm{~h}$, and declined thereafter to lower levels (Fig. 2). The aminase activity was about five times lower at all times. Candicidin production in SPG medium started at $15 \mathrm{~h}$, coinciding with the time of appearance of PABA synthase activity. A similar pattern of enzyme formation and disappearance has been found in several enzymes of secondary metabolism (Martín \& Demain, 1980). No PABA synthase activity was detected in cells grown in YED (Fig. 2) or minimal medium (not shown), two media that do not support candicidin biosynthesis. 


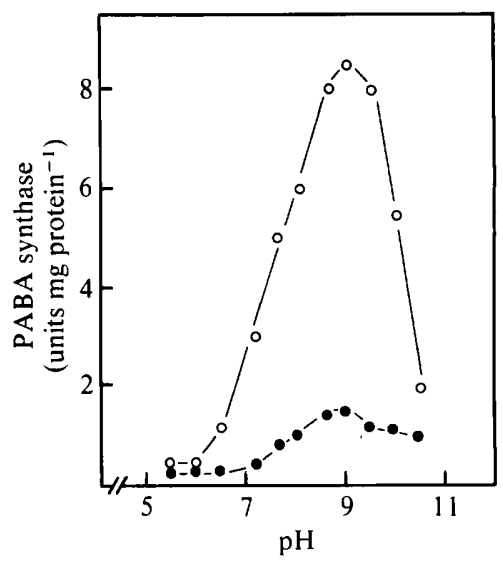

Fig. 1. Optimal pH of amidotransferase and aminase activities of PABA synthase in crude extracts. Amidotransferase $(O)$ and aminase $(O)$ activities were determined as indicated in Methods, in extracts of cells grown in SPG medium for $20 \mathrm{~h}$. Tris/maleate buffer $(10 \mathrm{mM})$ was used in the $\mathrm{pH}$ range 5.5 to 6.5 , Tris $/ \mathrm{HCl}(10 \mathrm{~mm})$ in the $\mathrm{pH}$ range 7.2 to 9.0 and carbonate buffer $(10 \mathrm{~mm})$ in the $\mathrm{pH}$ range 9.5 to 10.5 .

\section{Partial purification and enzyme kinetics of $P A B A$ synthase}

PABA synthase was purified from batches of $S$. griseus grown in SPG medium for $20 \mathrm{~h}$ and disrupted as indicated in Methods. Enzyme extracts $(280 \mathrm{mg}$ protein in $70 \mathrm{ml})$ were dialysed against DMG buffer for $10 \mathrm{~h}$ at $4{ }^{\circ} \mathrm{C}$ with buffer changes every $2 \mathrm{~h}$. The dialysed extracts were chromatographed on DEAE-Bio-gel followed by elution with a linear gradient of 0 to $1 \mathrm{M}-\mathrm{NaCl}$ in DMG buffer. The enzyme activity was eluted as a single symmetrical peak at a $\mathrm{NaCl}$ concentration of $0.6 \mathrm{M}$. The eluted enzyme was dialysed against DMG buffer for $2 \mathrm{~h}$, concentrated by batchwise absorption on a small DEAE-Bio-gel column and eluted with $0.8 \mathrm{M}-\mathrm{NaCl}$ in DMG buffer. After a second dialysis the enzyme was chromatographed on a Sephacryl S- 200 gel. The molecular weight of the enzyme was estimated to be 50000 from its elution behaviour after gel filtration on Sephacryl S-200 as compared with standards of known molecular weight (Fig. 3). Purification of the enzyme was achieved only for the amidotransferase activity because the aminase activity was undetectable after column chromatography, even in the presence of $\mathrm{MgCl}_{2}$ or glycerol (Table 1).

Double reciprocal plots were made of the reaction velocity of PABA synthase against glutamine concentration at five potassium chorismate concentrations $(0.015-0.05 \mathrm{mM})$ and against potassium chorismate concentration at four glutamine concentrations $(5-40 \mathrm{~mm})$. Both series of plots gave sets of convergent lines, suggesting that the reaction proceeds by a sequential mechanism. The apparent $K_{\mathrm{m}}$ values for chorismic acid and for L-glutamine were $6.6 \times 10^{-5} \mathrm{M}$ and $7 \cdot 1 \times 10^{-3} \mathrm{M}$ respectively.

\section{Regulation of $P A B A$ synthase}

Inhibition. In vitro PABA synthase (amidotransferase) activity from $S$. griseus was not subject to product inhibition by PABA. It was also insensitive to inhibition by anthranilic acid, aromatic amino acids, phosphate, ATP, glucose 6-phosphate or fructose 1,6-diphosphate.

Repression by aromatic amino acids. The effect of aromatic amino acids on PABA synthase was studied using phosphate-limited resting cells of $S$. griseus. Aromatic amino acids were added immediately following their suspension in PLD medium and samples were taken $8 \mathrm{~h}$ later. The results shown in Fig. 4 indicate that tyrosine, phenylalanine and tryptophan repressed the formation of PABA synthase. The extent of this repression was greater than the reduction of candicidin biosynthesis, probably because we measured total candicidin accumulated during $8 \mathrm{~h}$ and not the rate of antibiotic biosynthesis at a specific time.

Regulation by anthranilic acid and PABA. Candicidin biosynthesis was clearly reduced by addition of anthranilic acid and PABA which might be due to repression of PABA synthase. 


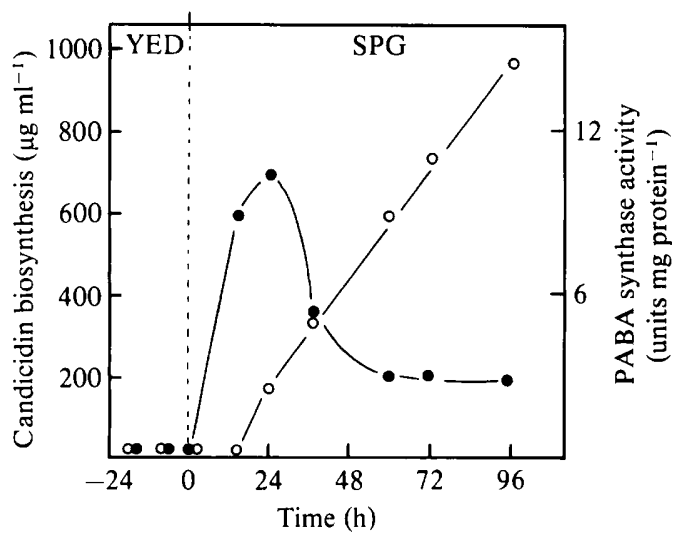

Fig. 2

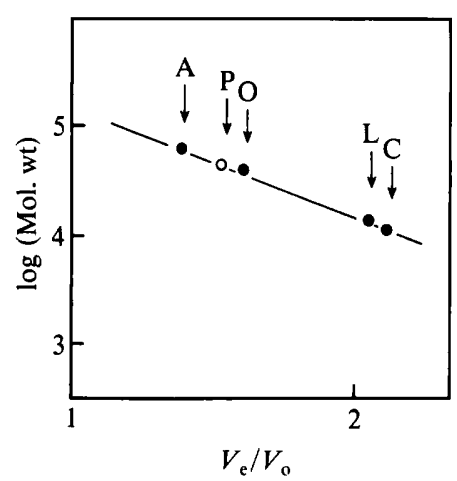

Fig. 3

Fig. 2. Time-course of PABA synthase (amidotransferase) activity $(O)$ and candicidin biosynthesis $(O)$ during batch cultures of $S$. griseus. PABA synthase activity was determined in cell-free extracts prepared from cells taken at different times from the inoculum (YED) or production (SPG) medium.

Fig. 3. Determination of the molecular weight of PABA synthase (amidotransferase) activity by gel filtration on Sephacryl S-200 previously calibrated with proteins of known molecular weight (O): A, bovine albumin $(66200) ; \mathrm{O}$, ovalbumin $(46000)$; L, L-lysozyme (14600); C, cytochrome $c(12400)$. P, PABA synthase $(O)$.

Table 1. Partial purification of PABA synthase of $S$. griseus

$\begin{array}{lcccccc}\begin{array}{c}\text { Purification } \\ \text { step }\end{array} & \begin{array}{c}\text { Volume } \\ (\mathrm{ml})\end{array} & \begin{array}{c}\text { Activity } \\ \left.\text { (units } \mathrm{ml}^{-1}\right)\end{array} & \begin{array}{c}\text { Protein } \\ \left(\mathrm{mg} \mathrm{ml}^{-1}\right)\end{array} & \begin{array}{c}\text { Specific } \\ \text { activity } \\ \text { (units mg } \\ \left.\text { protein }^{-1}\right)\end{array} & \begin{array}{c}\text { Purification } \\ \text { (fold) }\end{array} & \begin{array}{c}\text { Percentage } \\ \text { recovery }\end{array} \\ \text { Cell extract } & 70 & 38 & 4 & 9 \cdot 5 & - & 100 \\ \text { DEAE-Bio-gel } & 20 & 56 & 2 \cdot 4 & 23 \cdot 4 & 2 \cdot 45 & 49 \\ \text { Sephacryl S-200 } & 16 & 8 & 0 \cdot 064 & 125 & 13 \cdot 15 & 5 \cdot 6\end{array}$

Addition of exogenous PABA to the culture decreased the PABA synthase in the cells by $67 \%$, but anthranilic acid had no effect. On the other hand, candicidin production was decreased by addition of anthranilic acid ( $52 \%)$ and PABA $(27 \%)$. Similar experiments were done on resting cells to avoid interference by growth-related factors. Under these conditions, candicidin biosynthesis was inhibited $(30 \%)$ by anthranilic acid, but the activity of PABA synthase was again not reduced. Since anthranilic acid inhibited candicidin production but did not repress PABA synthase, it seems that its effect was exerted at a different level.

\section{Control of PABA synthase formation by phosphate}

The well-known inhibitory effect of inorganic phosphate on candicidin biosynthesis (Martín \& Demain, 1976) was correlated with the reduction of PABA synthase both in SPG and in PLD suspension medium. Increasing phosphate concentrations had a higher inhibitory effect on candicidin biosynthesis and PABA synthase activity (Fig. 5). Potassium phosphate at 5 to $10 \mathrm{~mm}$ almost completely repressed both PABA synthase activity and candicidin biosynthesis.

PABA synthase was derepressed by potassium phosphate starvation. Cells grown for $24 \mathrm{~h}$ in SPG medium supplemented with 5 mM-potassium phosphate (in which both PABA synthase and candicidin are repressed) were transferred to phosphate-limited and phosphatesupplemented (5 mM) PLD medium (Fig. 6). Transfer to phosphate-limited medium resulted in an almost immediate formation of PABA synthase and accumulation of candicidin, whereas transfer to PLD medium supplemented with $5 \mathrm{mM}$-phosphate resulted in neither derepression of enzyme nor formation of candicidin. 


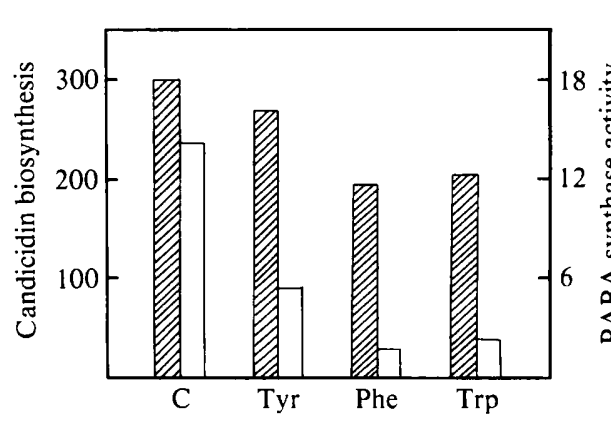

Fig. 4

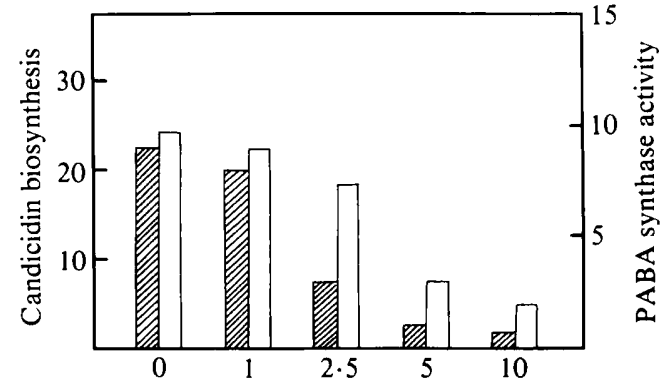

Initial concn of potassium phosphate added (mM)

Fig. 5

Fig. 4. Repression of PABA synthase by aromatic amino acids. Resting cell cultures of $S$. griseus in PLD medium were supplemented with either $10 \mathrm{mM}$-L-tryrosine (Tyr), L-phenylalanine (Phe) or Ltryptophan (Trp). Controls (C) were not supplemented. Candicidin biosynthesis $(\mathbb{C})$ and PABA synthase activity $(\square)$ were determined after $8 \mathrm{~h}$ incubation; results are expressed as $\mu \mathrm{g} \mathrm{ml}^{-1}$ and units mg protein ${ }^{-1}$, respectively.

Fig. 5. Repression by phosphate of PABA synthase activity ( $\square$ ) and candicidin biosynthesis $(\square)$. Cultures were incubated for $20 \mathrm{~h}$ in phosphate-supplemented or unsupplemented SPG medium. Results are expressed as $\mu \mathrm{g}\left(\mathrm{mg}\right.$ dry $\mathrm{wt}^{-1}$ for candicidin biosynthesis and units $\mathrm{mg}$ protein ${ }^{-1}$ for PABA synthase activity.

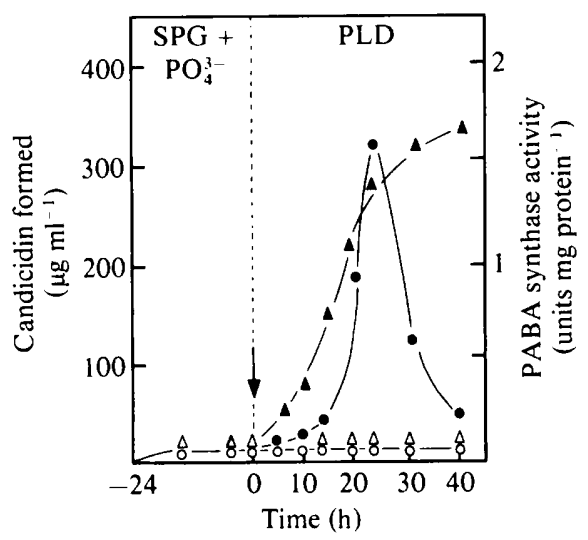

Fig. 6. Derepression of PABA synthase activity following phosphate starvation. Cells of $S$. griseus incubated in SPG medium supplemented with $5 \mathrm{mM}$-phosphate [in which both PABA synthase activity $(O)$ and candicidin formation $(\triangle)$ were repressed] were collected, washed in saline solution and transferred to phosphate-free $(\boldsymbol{O}, \boldsymbol{\Delta})$ and phosphate-supplemented $(5 \mathrm{~mm})(O, \triangle)$ PLD medium at $0 \mathrm{~h}$ (arrow). $\triangle . \Delta$. Candicidin formed;, $\mathbf{O}$, PABA synthase activity.

\section{$P A B A$ synthase activity in non-producing mutants of $S$. griseus and in different Streptomyces strains}

A total of 32 non-producing mutants of $S$. griseus were obtained after screening 25000 colonies obtained by treatment with UV light for lack of formation of an inhibition zone against Candida utilis; they produced no candicidin in SPG medium as assayed by either spectrophotometry or TLC. All possible pairs of mutants were unable to produce antibiotic by cosynthesis in solid medium. None of these mutants were auxotrophs, as tested in PABA-free defined medium solidified with pure agarose (Sigma). Under these conditions, PABA auxotrophs of $S$. lividans JG10 and $S$. coelicolor 2280 failed to grow. Cell-free extracts of the non-producing mutants grown in SPG medium prepared at different times of the growth cycle had no detectable PABA synthase. Residual PABA synthase activity below the detection level $(0.5$ units $)$ might, however, be sufficient to form the amount of PABA required for folic acid synthesis. 
In order to test whether PABA synthase is involved exclusively in secondary metabolism or is also involved in vitamin synthesis, we assayed the enzyme activity in cell-free extracts from various prototrophic Streptomyces species grown in SPG medium. We could not detect PABA synthase throughout the culture cycle in $S$. griseus NRRL 3851 (producer of cephamycins A and B), $S$. lividans 66 or $S$. coelicolor M145. However, PABA synthase activity was found in $S$. coelicolor var. aminophilus, the fungimycin producer. Fungimycin is an aromatic polyene antibiotic similar to candicidin, containing an $n$-methyl-p-aminoacetophenone moiety instead of $p$-aminoacetophenone.

\section{DISCUSSION}

PABA synthase activity exhibited both aminase and amidotransferase activities in crude extracts. Enzyme activity with glutamine as amino donor was 5- to 10-fold higher than with ammonia. The aminase activity could not be assayed in purified preparations because of its high lability. Several microbial enzymes that transfer amino groups may act as amidotransferases or aminases (Buchanam, 1973). Anthranilate synthase of $S$. griseus IMRU 3570 had a similar optimal $\mathrm{pH}(8.5)$ and temperature $\left(30^{\circ} \mathrm{C}\right)$ to PABA synthase but it differs in having mainly aminase rather than amidotransferase activity (G. Naharro \& J. F. Martín, unpublished results). The amidotransferase activity of the PABA synthase of Bacillus subtilis is 5- to 10-fold higher than the aminase activity (Kane \& O'Brien, 1975), as we observed in $S$. griseus, whereas the anthranilate synthase of a chloramphenicol-producing strain of Streptomyces venezuelae has similar amidotransferase and aminase activities (Francis et al., 1978). Sensitivity of PABA synthase to EDTA and its activation by $\mathrm{Mg}^{2+}$ ions have also been reported for the PABA synthase of $B$. subtilis (Kane \& O'Brien, 1975). PABA synthase activity in $S$. griseus was about seven times higher at maximal levels than in E. coli $\mathrm{HB101}\left(8.2\right.$ and 1.2 units mg protein ${ }^{-1}$, respectively) (A. Rebollo, P. Liras, J. A. Gil \& J. F. Martín, unpublished results) and about 1.5to 2-fold higher than in B. subtilis (Kane \& O'Brien, 1975).

The time-course of PABA synthase activity follows a pattern similar to that of most other enzymes of secondary metabolism (Martín \& Demain, 1980). No PABA synthase activity was found in the phosphate-rich YED medium used for inoculation. PABA synthase activity in SPG medium was first detected 12 to $15 \mathrm{~h}$ after inoculation, coinciding with the time of depletion of inorganic phosphate in the medium and a sharp drop in the rate of RNA synthesis (Liras et al., 1977).

PABA synthase, purified by gel filtration on DEAE-Bio-gel and Sephacryl S-200, had an approximate molecular weight of 50000 . This compares with the PABA synthase of $B$. subtilis which is composed of two non-identical subunits A (mol. wt 31000) and X (mol. wt 19000) (Kane \& O'Brien, 1975), but is slightly smaller than the PABA synthase of $E$. coli which consists of two subunits of molecular weight 48000 and 9000 , respectively (Huang \& Gibson, 1970), although the second (amidotransferase) subunit has recently been shown to contain 187 amino acids and have a molecular weight of 20752 (Kaplan \& Nichols, 1983). In B. subtilis and E. coli, PABA synthase activity was separated into two peaks by gel filtration. However, PABA synthase of $S$. griseus could not be separated into two active fractions. This result correlates with the finding that one single $3.5 \mathrm{~kb}$ DNA fragment carrying the PABA synthase gene of $S$. griseus complements both $E$. coli mutants $p a b A$ and $p a b B$ that are located at 40 and 74 min of the E. coli map (Gil \& Hopwood, 1983), although it does not exclude the possibility of two linked genes existing in this fragment (Martín \& Gil, 1984).

An important result in relation to the control of antibiotic biosynthesis is that PABA synthase is strongly repressed, but not inhibited, by phosphate. Neither ATP, fructose 1,6-diphosphate or glucose 6-phosphate had any detectable inhibitory effect on PABA synthase activity in vitro. Derepression of PABA synthase occurred following a shiftdown in phosphate concentration (Fig. 6). Inorganic phosphate is a crucial growth-limiting nutrient for biosynthesis of polyene macrolide antibiotics (Martín, 1977). The onset of candicidin biosynthesis is triggered by phosphate depletion (Liras et al., 1977). Phosphate repression of PABA synthase explains the 
lack of enzyme activity in inoculum cultures grown in YED (a phosphate-rich medium) and the delay in the onset of candicidin biosynthesis in cultures supplemented with high concentrations of phosphate (Liras et al., 1977). Only when phosphate is depleted does formation of PABA synthase, leading to candicidin biosynthesis, occur (Fig. 2).

PABA synthase activity was not detected in several other species of Streptomyces, including strains of $S$. griseus that produce cephamycin instead of candicidin. However, this enzyme was found in $S$. coelicolor var. aminophilus which produces fungimycin, an aromatic polyene antibiotic similar to candicidin. Hybridization of total DNA of several Streptomyces species with a probe carrying the PABA synthase ( $p a b$ ) gene from $S$. griseus (Gil \& Hopwood, 1983) suggests that this gene is absent in Streptomyces species which do not produce candicidin, i.e. it appears to be a specific gene for biosynthesis of secondary metabolites.

The 32 mutants of $S$. griseus blocked in candicidin biosynthesis lacked PABA synthase. However, they were not auxotrophs when tested in defined medium solidified with pure agarose. PABA auxotrophs of $S$. coelicolor and $S$. lividans did require exogenous PABA for growth under these conditions, suggesting that the lack of PABA requirement by mutants of $S$. griseus lacking PABA synthase is due either to a residual level of this enzyme below the threshold detection level, or to the formation of enough PABA by other aromatic amidotransferases (e.g. anthranilate synthase) existing in the cell. The possible existence of two different PABA synthases for vitamin biosynthesis and for candicidin formation is currently being investigated.

Blocked mutants may also lack other enzymes involved in candicidin biosynthesis in addition to PABA synthase.

This work was supported in part by grants from the Comisión Asesora de Investigación Científica y Técnica (CAICYT) Madrid, and Antibióticos, SA, Madrid, Spain. We acknowledge the help of D. A. Hopwood in correcting the manuscript.

\section{REFERENCES}

Altendorf, K. H., Gilch, B. \& Lingens, F. (1971). Biosynthesis of p-aminobenzoic acid in Aerobacter aerogenes. FEBS Letters 16, 95-98.

BUChANAM, J. M. (1973). The amidotransferases. Advances in Enzymology 39, 91-183.

Francis, H. H., Vining, L. C. \& Westlake, D. W. S. (1978). Characterization and regulation of anthranilate synthetase from a chloramphenicol-producing streptomycete. Journal of Bacteriology 134, 1016.

GibSON, F. (1970). Preparation of chorismic acid. Methods in Enzymology 17A, 362-364.

Gibson, F., Gibson, M. \& Cox, G. B. (1964). The biosynthesis of p-aminobenzoic acid from chorismic acid. Biochimica et biophysica acta 82, 637-638.

GIL, J. A. \& HoPwOOD, D. A. (1983). Cloning and expression of a p-aminobenzoic acid synthetase gene of the candicidin producer Streptomyces griseus. Gene 25, 119-132.

Gil, J. A., Liras, P., Naharro, G., Villanueva, J. R. \& MARTín, J. F. (1980). Regulation by aromatic amino acids of the biosynthesis of candicidin by Streptomyces griseus. Journal of General Microbiology 118, 189-195.

HoPWOOD, D. A. (1969). Genetic analysis and genome structure in Streptomyces coelicolor. Bacteriological Reviews 31, 373-403.

Huang, M. \& Gibson, F. (1970). Biosynthesis of paminobenzoate in Escherichia coli. Journal of Bacteriology 102, 767-773.

JoNES, A. \& WestLAKe, D. W. S. (1974). Regulation of chloramphenicol synthesis in Streptomyces sp. 3022a. Properties of arylamine synthetase, an en- zyme involved in antibiotic synthesis. Canadian Journal of Microbiology 20, 1599-1611.

KANE, J. F. \& O'BriEN, H. D. (1975). P-aminobenzoate synthase from Bacillus subtilis: amidotransferase composed of nonidentical subunits. Journal of Bacteriology 123, 1131-1138.

Kaplan, J. B. \& Nichols, B. P. (1983). Nucleotide sequence of Escherichia coli pab A and its evolutionary relationship to trp (G)D. Journal of Molecular Biology 168, 451-468.

Liras, P., Villanueva, J. R. \& Martín, J. F. (1977). Sequential expression of macromolecule biosynthesis and candicidin formation in Streptomyces griseus. Journal of General Microbiology 102, 269-277.

LiU, C. M., McDaniel, L. E. \& Schaffner, C. P. (1972). Studies on candicidin biosynthesis. Journal of Antibiotics 25, 116-121.

Martín, J. F. (1977). Biosynthesis of polyene macrolide antibiotics. Annual Review of Microbiology 31, 13-38.

Martín, J. F. \& Demain, A. L. (1976). Control by phosphate of candicidin production. Biochemical and Biophysical Research Communications 71, 1103-1109.

Martín, J. F. \& Demain, A. L. (1980). Control of antibiotic biosynthesis. Microbiological Reviews 44, 230-251.

Martín, J. F. \& Gil, J. A. (1984). Cloning and expression of antibiotic production genes. Bio/Technology 2, 63-72.

MARTín, J. F. \& LiRAs, P. (1976). Rapid incorporation of precursors into candicidin by resting cells of Streptomyces griseus. Journal of Antibiotics 29, 1306 1309. 
Martín, J. F. \& McDaniel, L. E. (1975a). Trophophase-idiophase transition in polyene macrolide antibiotics fermentations: cell maturation time. Biotechnology and Bioengineering 17, 208-214.

Martín, J. F. \& McDaniel, L. E. (1975b). Specific inhibition of candicidin biosynthesis by the lipogenic inhibitor cerulenin. Biochimica et biophysica acta 411, 186-194.
ZIELINSKI, J., Borowy-Borowsky, H., Golik, J., GumieniaK, J., Ziminsky, T., KolodZy-EJCZYK, P., PAWLAK, J. \& BorowsKi, E. (1979). The structure of levorin $\mathrm{A}_{2}$ and candicidin D. Tetrahedron Letters 20 , 1791-1794.

ZishKa, M. K. \& Nishimura, J. S. (1970). Effect of glycerol on Lowry and Biuret methods of protein determination. Analytical Biochemistry 34, 291-297. 